UDC 332.1

DOI: https://doi.org/10.32782/2415-8801/2020-6.2

Stoyanets Nataliya

Sumy National Agrarian University, Ukraine ORCID: https://orcid.org/0000-0002-7526-6570

Yuanyuan Xia

Sumy National Agrarian University, Ukraine ORCID: https://orcid.org/0000-0002-4614-4961

Jialong Shen

Henan Institute of Science and Technology, China ORCID: https://orcid.org/0000-0001-6703-4887

\title{
POPULARIZATION OF PRESCHOOL EDUCATION IN THE CONTEXT OF RURAL HUMAN RESOURCES DEVELOPMENT
}

A review of the development of preschool education since the reform and opening of China over the past 42 years, an analysis of the process of promoting preschool education in rural areas against the background of human resources development in rural areas and a summary of China's experience. It was determined that the transfer of surplus labor in rural areas contributed to the development of preschool education. Preparation for employment and training of employees of preschool educational institutions after the end of work improve the quality of preschool education. National policy provides a sufficient guarantee to increase the level of promotion of preschool education. It is suggested that in order to improve the quality of preschool education in the future, the popularization of preschool education should be taken into account. The development of pre-school education in China since the reform provides great prospects, especially for the promotion of pre-school education in the light of rural human resources development, and provides reliable links to future rural human resources development and rural policy development in China and other developing countries.

Keywords: reform, preschool education development, human resources, rural areas, China's experience, national curriculum.

\section{ПОПУЛЯРИЗАЦІЯ ДОШКІЛЬНОЇ ОСВІТИ В КОНТЕКСТІ РОЗВИТКУ СІЛЬСЬКИХ ЛЮДСЬКИХ РЕСУРСІВ}

\author{
Стоянець Н.В. \\ доктор економічних наук, \\ професор кафедри менеджменту, \\ Сумський національний аграрний університет \\ Юануянь Сиа \\ аспірант, \\ Сумський національний аграрний університет \\ Ялонг Шен \\ професор, \\ Інститут науки і техніки Хенань, Китай
}

Проведено огляд стану розвитку дошкільної освіти з часу реформування Китаю за останні 42 роки, аналіз процесу популяризації дошкільної освіти в сільській місцевості на фоні розвитку людських ресурсів у сільській місцевості та узагальнення досвіду Китаю. Визначено Китай, як найбільша крайна, щцо розвивається у всьому світі, за останні 42 роки досяг значних досягнень у галузі національного економічного обліку, засобів існування людей, енергетики, зовнішньоекономічної торгівлі, сільського господарства, основних галузей промисловості, включаючи дошкільну освіту. Це дослідження в основному представляє великий прогрес у популяризації дошкільної освіти в Китаї з часу реформування та відкриття. Беручи за основу розвитоклюдських ресурсів у селі, аналіз досвіду Китаю в популяризації доикільної освіти робить наступні висновки. Політика розвитку сільської дошкільної освіти, створення системи дитячих садочків та побудова педагогічних колективів значно сприяли адаптації, відновленню та розвитку сільської дошкільної освіти Перерахування надлишку праці в сільській місцевості сприяло розвитку дошкільної освіти. Підготовка до працевлаштування та підготовка працівників дошкільних навчальних закладів після закінчення роботи покращують якість дошкільної освіти. Національна політика забезпечує достатню гарантію для збільшення рівня популяризації дочкільної освіти. Такожс пропонується, для покращення якості дошкільної освіти в майбутньому повинно враховуватися при подальщій популяризації дошкільної освіти. Орихінальність дослідження визначає аналіз розвиток дошкільної освіти 
Китаю з часу реформування та відкриття з багатьох перспектив. Особливо аналізується досвід популяризації дошкільної освіти з огляду на розвиток людських ресурсів у селі. Проаналізовано, щио істотне збільщення рівня проникнення дошкільної освіти у сільській місцевості з моменту реформування та відкриття, це дослідження узагальнюс досвід Китаю та забезпечує надійні посилання на майбутній розвиток сільських людських ресурсів та формулювання політики, пов'язаної з сільськими територіями в Китаї та інших краӥнах, це розвиваються y cвimi.

Ключові слова: реформа, розвиток дошкільної освіти, людські ресурси, сільська місчевість, досвід Китаю, національна програма навчання

Introduction and review of literature. China is a large agricultural developing country with an enormous rural population, which totals 552 million by 2020 [1]. Rural development is related to the development of the whole country, while the improvement of rural population quality is vital to the overall national quality level. Therefore, the development of preschool education has an absolutely crucial role in improving the rural population quality and even the overall quality of the whole nation and is also the foundation project for the improvement of the national quality.

As early as the end of 2010, 5,115 middle school students in Shanghai won the first place in the Programme for International Student Assessment (PISA) for the first time, which attracted the attention of all countries in the world. These Shanghai students who took the test scored an average of 66 points higher in reading if they had attended preschool education over one year than those who had not attended preschool education [2]. According to the research report from World Bank, investing in early childhood education may be the most cost-effective way in improving the living standards of the next generation in China, with economic returns of up to $7-18 \%$, which is much higher than financial capital investments [3, p. 352]. Coincidentally, longitudinal tracking from the American Perry Preschool Study [4] and a study conducted by Nobel Laureate David Heckman and his colleagues [5] found similar results. It is obvious that high-quality preschool education has a fundamental role in improving national quality all around the world, especially impoverished areas, and building national wealth, and it has a long-term comprehensive effect.

In fact, as preschool education involves the construction of social public service system and the satisfaction of the primary needs of people's livelihood, it has always been one of the crucial points for education reform of the Chinese government. China's preschool education has made tremendous progress since the reform and opening up in 1978. In 2019, the universality of education at all levels reached or exceeded the average level of middleand high-income countries. Actually, preschool education policies have been significantly inclined to rural areas and impoverished areas in China's central and western regions since 2010. Focusing on rural areas, the development of rural human resources has played a pivotal role in promoting the popularization of preschool education. By concluding and summarizing the experience of preschool education development in rural China, the construction of the preschool education system could be better promoted. For other developing countries, China's experience has reference value and could provide them with reference to the development of rural human resources.

The purpose of the article is to review the development of preschool education since China's reform and opening up in the past 42 years and summarize the experiences in preschool education popularization in China's rural areas under the background of rural human resources development.

Results and discussion. Before 1978, China experienced the mighty "Ten-year Cultural Revolution", and the domestic development situation was grim. Internationally, the developed countries were undergoing the third technological revolution with rapid economic development. Against such a background, China must carry out reform and opening up, which is the aspiration and choice of the whole party and the people of all ethnic groups. It is the most distinctive feature of contemporary China and the most distinctive background color of contemporary China. Over the past 42 years, China has made remarkable achievements along this road. In 2019, China's economic aggregate accounted for $16 \%$ of the world economy total, contributed $30 \%$ to world economic growth, and the economy scale remained the second largest place in the world [6, p. 18].

As shown in Table 1, China has made tremendous achievements in the fields of national economic accounting, people's livelihood, energy, foreign economic trade, agriculture and major industries. It is worth pointing out that these achievements are closely related to the rapid development of education, including preschool education. At present, China has entered a new socialist era, and the social principal contradiction has turned into contradictions between the people's ever-growing needs for a better life and unbalanced and insufficient development. In this new historical period, preschool education will still be an important field of education reform and also an important approach to realize balanced development of education.

1. Great progress in popularizing preschool education in China since the reform and opening up

In the course of reform and opening up in China, preschool education has made a significant breakthrough as a foundation project to improve the quality of the people. There has been a marked increase in the scale of preschool education from 1978 to 2019 (Figure 1). By 2019, there are 574,600 more children in kindergartens than in 2018, an increase of $1.23 \%$, while the gross enrollment rate of preschool education come up to $83.4 \%, 1.7 \%$ higher than that in 2018 [1]. The number of kindergartens, the number of full-time teachers, the number of children in kindergartens and the gross enrollment rate of preschool education in China have all increased significantly from 1978 to 2019.

China has always been an agricultural country with a large rural population. Vigorously developing rural preschool education is of great significance to promoting the development of national preschool education, improving the quality of basic education and the overall quality of the whole nation. Statistics show that 8.81 million children were enrolled in kindergartens in counties, towns and rural areas in 1982 , accounting for $79.2 \%$ of the total number of 
Table 1

Indicators of total amount and speed of national economic and social development

\begin{tabular}{|l|c|c|c|c|}
\hline \multirow{2}{*}{\multicolumn{1}{|c|}{ Indicators }} & \multicolumn{2}{c|}{ Total amount } & \multicolumn{2}{c|}{ Average growth rate (\%) } \\
\cline { 2 - 5 } & $\mathbf{1 9 7 8}$ & $\mathbf{2 0 1 9}$ & $\mathbf{1 9 7 9 - 2 0 1 9}$ & $\mathbf{2 0 0 1 - 2 0 1 9}$ \\
\hline gross national income (100 million yuan) & 3678.7 & 988528.9 & 9.4 & 9.1 \\
\hline gross domestic product (100 million yuan) & 3678.7 & 990865.1 & 9.4 & 9.0 \\
\hline per capita gross national income (yuan) & 384.7 & 70891.8 & 8.4 & 8.4 \\
\hline per capita disposable income of households (yuan) & 171 & 30733 & 8.4 & 9.2 \\
\hline total energy production (10 thousand tons of SCE) & 62770 & 397000 & 4.6 & 5.7 \\
\hline $\begin{array}{l}\text { total energy consumption } \\
\text { (10 thousand tons of SCE) }\end{array}$ & 57144 & 487000 & 5.4 & 6.5 \\
\hline total value of import and export (100 million yuan) & 355.0 & 315627.3 & 18.0 & 11.6 \\
\hline $\begin{array}{l}\text { gross output value of agriculture, forestry, animal } \\
\text { husbandry and fishery (100 million yuan) }\end{array}$ & 1397.0 & 123967.9 & 5.5 & 4.5 \\
\hline cotton (10 thousand tons) & 216.7 & 588.9 & 2.5 & 1.5 \\
\hline aquatic products (10 thousand tons) & 465.4 & 6480.4 & 6.6 & 3.0 \\
\hline coal (100 million tons) & 6.2 & 38.46 & 4.6 & 5.5 \\
\hline natural gas (100 million cubic meters) & 137.3 & 1761.74 & 6.4 & 10.3 \\
\hline cement (100 million tons) & 6524.0 & 234430.6 & 9.1 & 7.5 \\
\hline
\end{tabular}

Source: developed by the authors based on the relevant original data in China Statistical Yearbook.

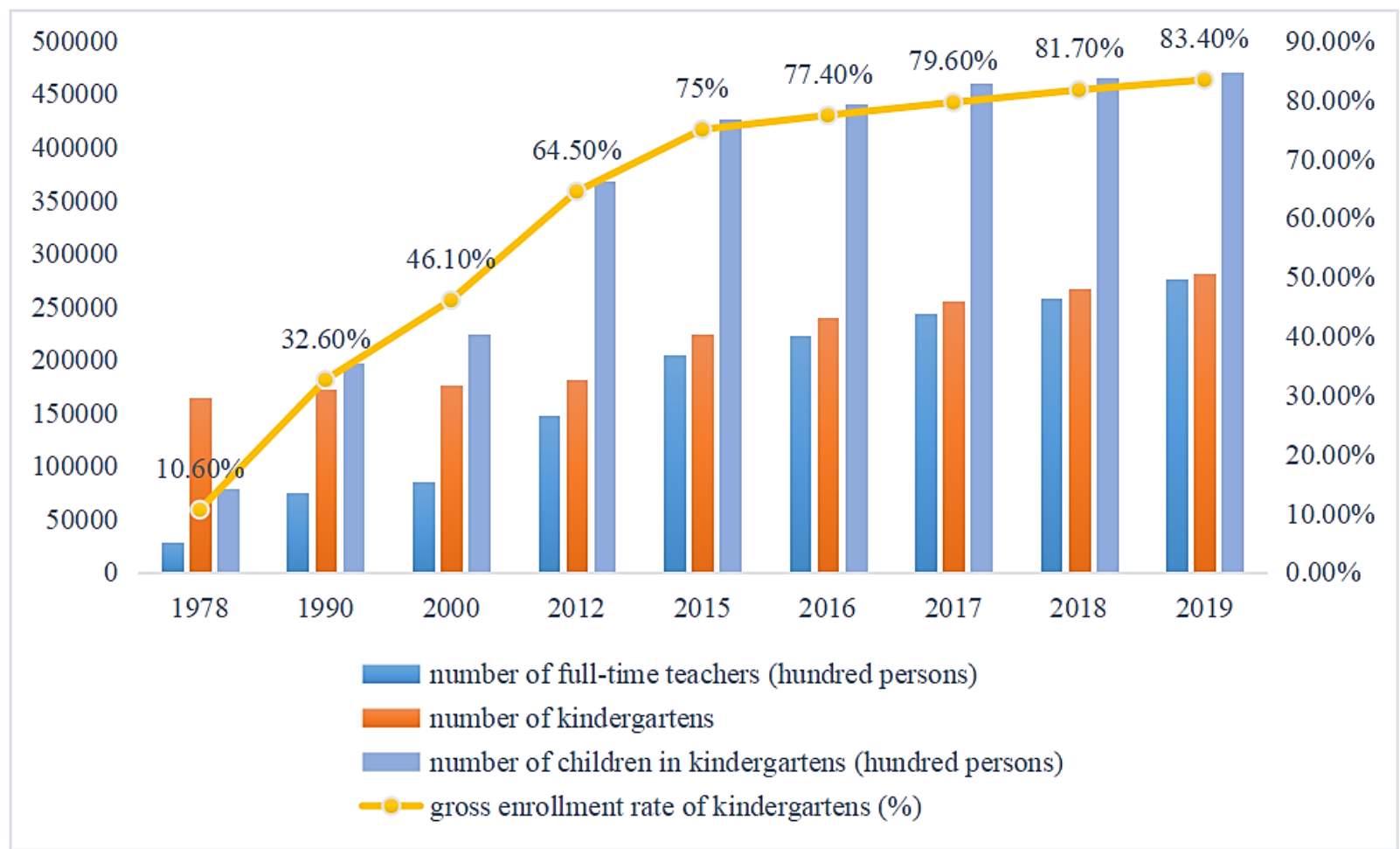

Figure 1. The scale of preschool education and gross enrollment rate in China since 1978

Source: calculated by authors based on National Education Development Statistical Bulletin

children enrolled in kindergartens nationwide, an increase of $35.7 \%$ over 1978 [7, p. 196]. As of 2018 , there were 94,051 kindergartens in rural areas, 453,134 classes, and $11,095,428$ children in the kindergartens, which accounted for $35.27 \%$ of the total number of kindergartens across the country [8, pp. 187-193]. These show that the popularization degree of preschool education in rural China has also been greatly improved. Why has China achieved such a breakthrough in the penetration rate of preschool education in 42 years? On the one hand, the popularization of preschool education further liberated a significant amount of labor force, especially the female labor force, improved the productivity, and greatly promoted the development of the national economy. On the other hand, the rational development of rural human resources effectively promoted the popularization of preschool education.

2. Expansionary effect of rural surplus labor transfer on the preschool education development

China has the most abundant labor resources in the world, and the labor force is mainly concentrated in the rural areas. However, because young children were mainly taken care of by families, part of labor, especially 
female labor, appeared surplus, which restricted the full use of human resources to a certain extent. In order to facilitate the development of the national economy, it is necessary to accomplish the transfer of rural surplus labor. Since the 1970s, China has carried out the rural surplus labor force transfer mainly through two ways. The first is to promote the transfer in agriculture by adjusting the internal structure of agriculture, which is the dominating way of rural surplus labor force transfer. The other way is to expand the employment field and opportunities by vigorously developing agriculture-related industries in the countryside, so as to achieve the transfer of agricultural surplus labor force to other non-agricultural industries in the countryside [9].

The realization of surplus rural labor force transfer made laborers have to send their children to preschool education institutions. Meanwhile, in order to better develop the rural surplus labor force and liberate the productive forces, their worries at home must be resolved, such as the education of young children. In 1979, the National Childcare Conference was held to reiterate that the principle of mutual development of public kindergartens and private kindergartens must be adhered, and specific guidance was put forward in the aspects of running kindergartens, teachers' treatment and training given the present situation of preschool education in rural areas. For instance, childcare organizations in rural areas need to be vigorously developed for farmers and their children, and perennial nurseries and kindergartens (classes) should be set up if conditions permit; The treatment of the personnel who care for and teach in the rural community and team kindergartens shall be equivalent to the remuneration of the same labor force; After the training assessment or outstanding work performance of the child-care personnel, their remuneration could be higher than the equivalent labor force; Preschool normal institutions should gradually train the backbone of preschool education for rural community nurseries and kindergartens [7]. The development policy of rural preschool education, the establishment of kindergarten system and the construction of teacher teams have greatly promoted the adjustment, restoration and development of rural preschool education. Besides, rural parents could send their children to kindergartens, which not only ensures the penetration rate of preschool education in rural areas but also greatly facilitate the development of domestic economy due to the liberation of productive forces.

As shown in Figure 2, China's gross domestic product in 2019 has increased by 98718.64 billion yuan from 1978, an increase of 268.4 times. Additionally, taking the basic employment situation in 2018 as an example, there were 205.28 million workers in the primary industry, 213.9 million workers in the secondary industry and 359.38 million workers in the tertiary industry. Among them, the rural population was 341.67 million, accounting for $44.04 \%$ of the total $[10$, p. 24]. It shows that rural employees have made a crucial contribution to China's economic development. Whether focusing on the present or long-term considerations, improving the quality of rural labor is the prerequisite for the successful transfer of rural surplus labor, which in turn depends on the popularization of rural fundamental education and the vigorous implementation of vocational education in China.

3. Improvement effect of the innovation of rural kindergarten teacher cultivating and training model on the preschool education quality

Over the past 42 years, the quality, structure and scale of teachers at all levels have been constantly improved. As of 2020, the total number of teachers at all levels has increased from 15.39 million in 2015 to 17.32 million, an increase of $12.5 \%$, which strongly supports the world's largest education system [11]. Since 2010, team construction of preschool teachers in rural China has also shown a good

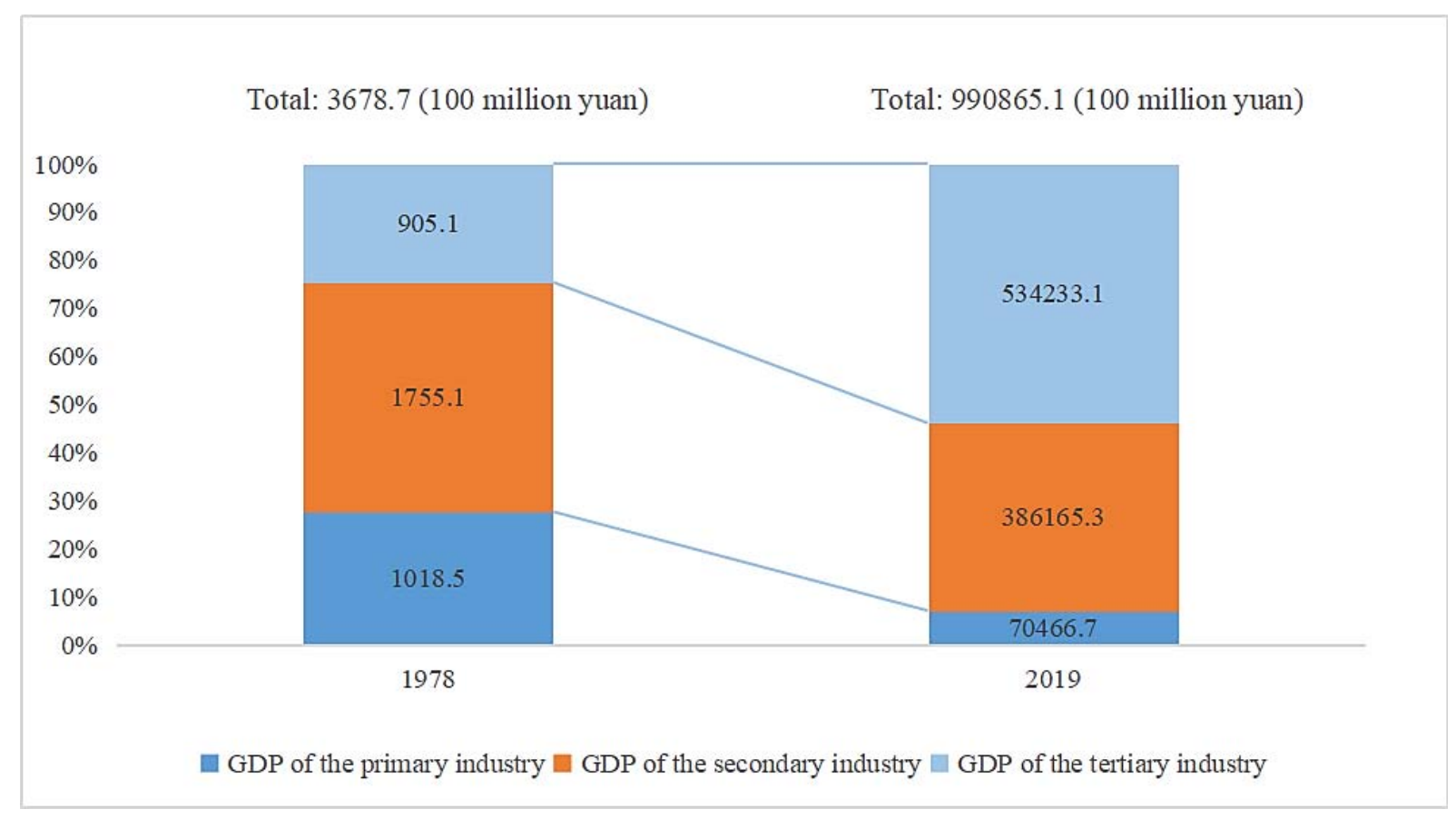

Figure 2. Comparison of GDP in different industry between 1978 and 2019

Source: developed by authors based on the relevant original data in China Statistical Yearbook 
momentum, forming a scene in which cultivation and training go hand in hand.

3.1. Innovation of pre-employment training model for rural kindergarten teacher. To alleviate the shortage of preschool education teachers in rural areas, China has continuously innovated the training model of kindergarten teachers in rural areas since 2010. Firstly, the training model of "Five-year Higher Vocational Education" for preschool teachers has been actively explored. "Opinions on the Current Development of Preschool Education" issued by China State Council indicated that it is necessary to actively explore the training model of five-year preschool teachers with specialized academic qualifications from the starting point of junior middle school graduation [12]. This innovation model integrates secondary vocational education and higher vocational education so that students and their families could gain higher educational benefits and returns with lower educational costs.

Secondly, the enrollment scale of free normal student programs in preschool education major has been expanded, and the training of preschool teachers in rural areas has been enhanced. For example, Shaanxi Province carried out the pilot work of free education for normal students in preschool education from 2013. The free normal students were exempted from tuition and accommodation fees during their study period, and were given certain living allowances. All the graduates trained need to be engaged in preschool education for more than ten years in kindergartens below the county or district level. Furthermore, measures such as "open recruitment" and "training provided" have been adopted to actively encourage qualified "non-normal major graduates" to engage in preschool education. Based on this, the average academic qualifications of full-time teachers and principals of rural kindergartens have been significantly improved year by year (Figure 3 ).

3.2. Special implementation of post-employment training for rural kindergarten teachers. To carry out postemployment training for preschool teachers is a necessary means to improve their competence and ensure the quality of education, which is as important as pre-employment training. In 2010, the "Several Opinions on the Current Development of Preschool Education" pointed out that a training system for kindergarten principals and teachers is necessary to be established, with 10,000 principals and key teachers being trained at the national level within three years, and all districts should conduct a round of professional training for all the kindergarten principals and key teachers within five years [12]. The Ministry of Education and Ministry of Finance jointly issued the "Notice on the Implementation of the National Training Plan for Preschool Teachers" in 2011 and stated to implement the national preschool teacher training plan nationwide, aiming at enhancing the team construction and improving the quality of rural preschool teachers [13]. The national training of kindergarten teachers is different from the training of kindergarten teachers in the general sense. It is a national and free training for kindergarten teachers for the first time. This training has a wide range of training objects and strong training intensity, and its influence is unmatched by other forms of training. The national training plan mainly adopts mixed training combining short-term intensive face-to-face instruction, online follow-up training and on-site classroom practice. The training team focuses on absorbing local first-line excellent teachers, teaching and research staff, and effectively integrating high-quality resources from colleges and districts. The training objects include principals, key teachers, and transfer teachers of rural public kindergartens and inclusive private kindergartens in the central and western regions in China.

Also, the central government has set up a special fund for the training of rural preschool teachers. The "Outline of the National Medium - and Long-term Education Plan" stipulates that the funds for teacher training should be included in the government budget, and in particular, the funds needed to implement the national training plan for preschool teachers should be supported by special funds allocated by the central finance [14]. On this basis, some local governments have also included the training funds

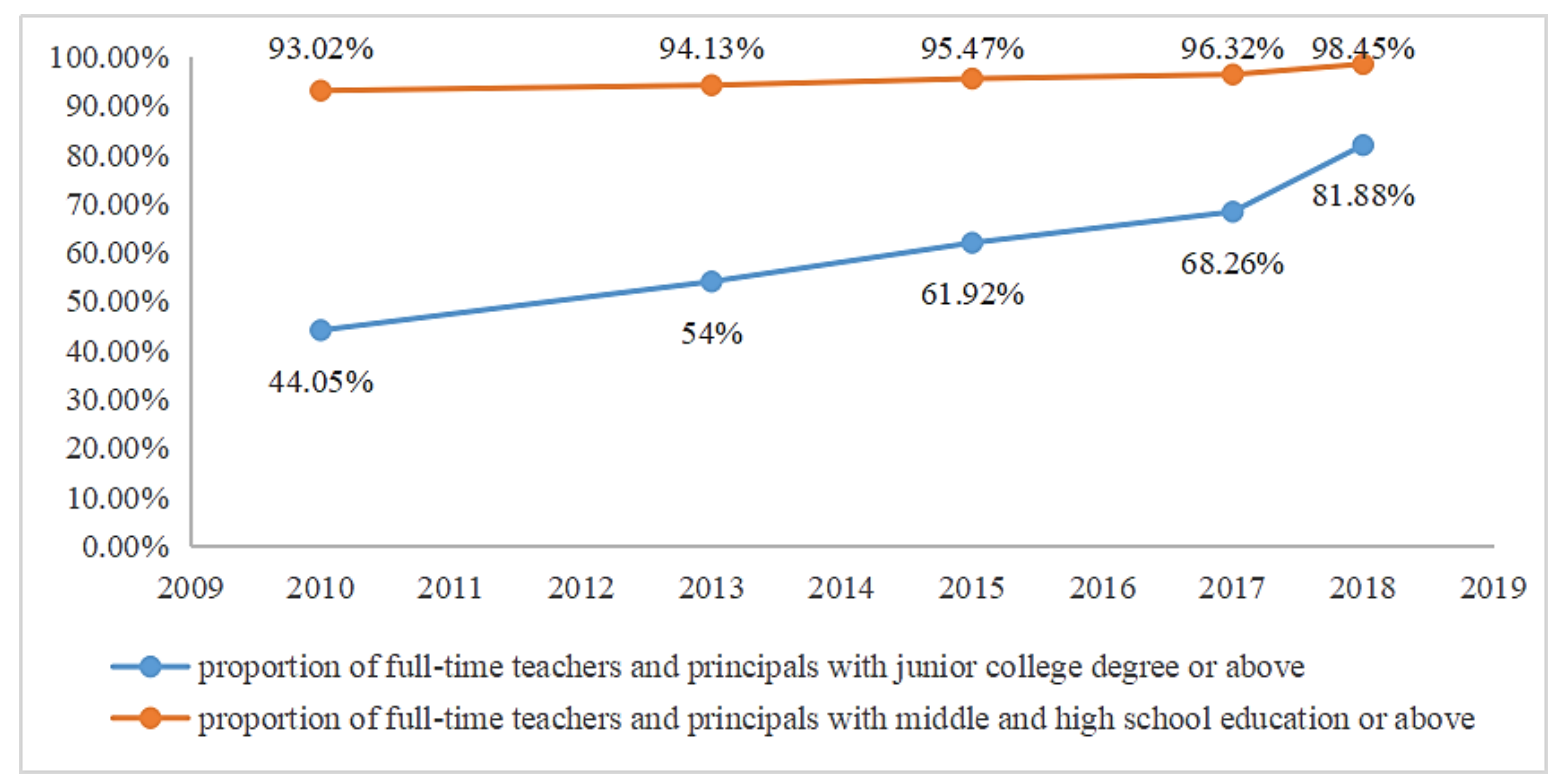

Figure 3. Average educational level of full-time teachers and principals in rural kindergartens

Source: calculated by authors based on relevant data in China Education Statistics Yearbook 
Main documents guaranteeing the popularization of preschool education since 1978

\begin{tabular}{|l|l|}
\hline Year & \multicolumn{1}{|c|}{ Documents } \\
\hline 1979 & Minutes of the National Childcare Meeting \\
\hline 1981 & Guidelines for Kindergarten Education (Trial Draft) \\
\hline 1983 & Notice on Several Issues Concerning Strengthening and Reforming Rural School Education \\
\hline 1983 & Suggestions on the Development of Rural Preschool Education \\
\hline 1986 & Supplementary Opinions on the Assessment of Kindergarten Teachers \\
\hline 1986 & Opinions on Further Running Preschool Classes \\
\hline 1989 & Working Regulations of Kindergarten \\
\hline 2016 & \\
\hline 2001 & Guidelines for Kindergarten Education (trial) \\
\hline 2003 & Guidelines on the Reform and Development of Early Childhood Education \\
\hline 2005 & Notice on standardizing the Training of Primary and Kindergarten Teachers \\
\hline 2008 & Decision on Several Major Issues Concerning Promoting Rural Reform and Development \\
\hline 2010 & Outline of the National Medium - and Long-term Plan for Education Reform and Development (2010-2020) \\
\hline 2010 & Several Opinions on the Current Development of Preschool Education \\
\hline 2011 & Notice on the Implementation of the National Training Plan for Preschool Teachers \\
\hline 2012 & Professional Standards for Kindergarten Teachers (trial) \\
\hline 2012 & Suggestions on Strengthening the Construction of Kindergarten Teachers \\
\hline 2013 & Suggestions on the Implementation of Poverty Alleviation Projects through Education \\
\hline 2015 & $\begin{array}{l}\text { Notice on the Measures for the Administration of Funds from the Central Finance for Supporting the Development of } \\
\text { Preschool Education }\end{array}$ \\
\hline 2016 & Education and Poverty Alleviation: The 13th Five-Year Plan \\
\hline 2018 & Suggestions on the Plan for Deepening Reform and Development of Preschool Education \\
\hline
\end{tabular}

for kindergarten teachers in their government budgets, providing a solid material guarantee for the training of rural preschool teachers.

4. Guarantee effect of relevant national policies on the preschool education popularization

Internationally, preschool education is regarded by many countries as an important "anti-poverty" initiative. Early effective interventions in childhood could fundamentally change the plight of poor children, thereby helping them achieve academic success and become productive adults [15]. The popularization of preschool education in rural areas is related to the improvement of the overall quality of preschool education and the implementation of the national human resource strategy. In the 42 years of reform and opening up, the state attached great importance to rural preschool education and issued a series of policies and documents (Table 2). These documents not only include the country's macro policy guidelines for the popularization of preschool education but also include specific requirements for preschool teachers, which have contributed to the rapid development of popularization and quality of preschool education in rural areas.

Conclusions. Since the reform and opening up, China's rural preschool education has made considerable progress. The primary reason is that the support of the national policy has provided a strong guarantee for improving the popularization rate and quality of preschool education. The leapfrog development of preschool education in rural areas in China's central and western regions and impoverished areas is the result of the establishment of a preschool education policy system, the full use of major projects, and continuous enrichment of poverty alleviation measures. China's policy is far-sighted, which has considered early childhood development and investment in preschool education as an effective way to break the vicious circle of poverty. The popularization of preschool education could not only improve the national quality and increase national wealth but also is an indispensable part of China's transition from a country with large human resources to a country with strong human resources.

Moreover, pre-employment training and postemployment training are important means of human resource development in rural preschool education. Through the transfer of rural surplus labor, China has improved productivity and promoted economic prosperity. The "Free Normal Students Training Program" and "National Training Program" for preschool teachers in rural areas are not only a means of developing rural human resources but also a feature of Chinese preschool education.

While promoting the popularization of preschool education, the improvement of education quality must be taken into account. Based on ensuring the popularization rate of preschool education, the quality of preschool education needs to be further strengthened. The professional quality of preschool teachers is the basic prerequisite and condition for kindergarten education quality. In addition to training and cultivating teachers for preschool education, the incentives are also needed to strengthen for teachers engaged in rural preschool education to enhance their professional identity and sense of responsibility. Correspondingly, when the occupation of kindergarten teachers becomes professional, the corresponding assessment mechanism also needs to be further improved.

Acknowledgments. This study is supported by the plan of general project subsidy for humanities and social science research of the Education Department of Henan province in China. The project is "Study on the current situation and training model of kindergarten teachers in Henan province under the policy of universal two-child policy" (No.: 2018- ZZJH-182). 


\section{References:}

1. The official site of National Bureau of Statistics of China (2020), China Statistical Yearbook 2020. Available at: http://www.stats.gov.cn/tjsj/ndsj/2020/indexch.htm.

2. PISA (2009), PISA 2009 results: Overcoming social background - Equity in learning opportunities and outcomes. Paris: OECD Publishing.

3. Wu K.B. (2011) Early childhood development and education in China: breaking the cycle of poverty and improving future competitiveness. World Bank Other Operational Studies, vol. 24, no. 3, pp. 350-376.

4. Schweinhart L.J., Montie J., Xiang Z., Barnett W.S., Belfield C.R., Nores M. (2005) Lifetime effects: The HighScope Perry Preschool study through age 40. Ypsilanti, MI: HighScope Press.

5. Heckman J.J., Moon S.H., Pinto R., Savelyev P.A., Yavitz A.Q. (2009) A reanalysis of the High / Scope Perry Preschool program. Available at: http://jenni.uchicago.edu/perry_reanalysis/general-090424-1808.pdf.

6. Ning J. (2020) China's economy is writing a new chapter. Wisdom China, no. Z1, pp. 18-21.

7. Chinese Society of Preschool Education (1999). A collection of important literature on early childhood education of the People's Republic of China. Beijing: Beijing Normal University Press.

8. Development Planning Department of the Ministry of Education of China (2019). China education statistics yearbook 2018. Beijing: China Statistics Publishing House.

9. Liu H. (2005) New theory of rural surplus labor transfer. Beijing: China Economic Press.

10. National Bureau of Statistics of China (2019). Statistical yearbook of China's population and employment 2019. Beijing: China Statistical Press.

11. The official site of the Ministry of Education of China (2020), Seized the opportunity to make key breakthroughs and went all out to deliver its proud work on the construction and reform of teachers in the new era. Available at: http://www.moe.gov.cn/fbh/live/2020/52692/sfcl/202012/t20201201 502589.html.

12. The official site of the Central People's Government of China (2010), Several opinions on the current development of preschool education. Available at: http://www.gov.cn/zhengce/content/2010-11/24/content 5421.htm.

13. The official site of the Ministry of Education of China (2011), Notice on the implementation of the national training plan for preschool teachers. Available at: http://www.moe.gov.cn/srcsite/A10/s7058/201109/t20110905 146630.html.

14. The official site of the Ministry of Education of China (2010), Outline of the national medium and long term plan for education reform and development (2010-2020). Available at: http://www.moe.gov.cn/srcsite/A01/s7048/201007/ t20100729_171904.htm.

15. Neuman S.B. (2011) Preschool education reform and national anti-poverty strategies: United States experience. Beijing: Education Science Press. 